\title{
Impact of "COVID-19" on the Life of Destitute People: A Soft-Measurement in Bangladesh
}

\author{
Razuan Ahmed Shuvro \\ Assistant Professor \\ Human Resource Management \\ Jatiya Kabi Kazi Nazrul Islam University \\ Trishal, Mymensingh, Bangladesh \\ E-mail: r.a.shuvro@jkkniu.edu.bd \\ Md. Mohosin Talukder \\ Ex-Lecturer in Human Resource Management \\ Department of Business Administration \\ Bangladesh University \\ Dhaka, Bangladesh \\ E-mail: mohosintalukder6@gmail.com
}

Received: July 2I, 2020

doi: $10.4628 \mathrm{I} /$ bjmsr.v2i2.723
Accepted: July 30, 2020

Online Published: August 22, 2020

URL: https://doi.org/I0.4628I/bjmsr.v2i2.723

\begin{abstract}
The world has been crippling due to COVID I9. This pandemic has affected the lives of everyone. But the people who belong to the lower ladder in socioeconomic status may suffer more due to COVID I9 in developing countries. This paper aimed to explore factors influenced by COVID I9 and their association with the impact of COVID I9 on the life of destitute people. To reach the aim, the authors adopted a quantitative approach. A field survey on a sample of 250 destitute people was conducted using a self-constructed questionnaire. Factor analysis (principle component) found that 5 factors are influenced by COVID 19 in the life of destitute people and these are mental trauma and fear, full of uncertainty, reduced income level, feeling helplessness, and health safety issues. With a composite mean of 3.4056 and 0.698 standard deviations often tangible and intangible aspects of life, the paper found a moderate negative impact of COVID I9 on the life of destitute people. Multiple regression analysis evinces that factors found in factor analysis can explain $67.2 \%$ variance and has a statistically significant association with the impact of COVID 19 on the life of destitute people and among the five factors mental trauma and fear are the most influential $(\beta .279, \mathrm{P}<0.05)$. Finally, this paper concluded that cogitation of factors found in this paper may help the authority to mitigate the negative impact of such pandemic on the life of destitute people in a developing country like Bangladesh.
\end{abstract}

Keywords: Impact of COVID 19, Destitute People, Mental Trauma, and Fear, Feeling Helplessness, Reduced Income Level.

\section{Introduction}

The 'Ribonucleic Acid' virus attack on the human being is not a new phenomenon. It has a more or less tremendous record of bringing sufferings for people in the world's history. The world has experienced many violent from viruses and lost millions of people before the natural departure of the soul. This type of disaster not only takes the life of people but also disrupt the whole system with domino effect and human impact. As the Scott (2020) opines that strategies to prevent transmission of the virus have some human impacts. Moreover, the uncertainty of the role that the pandemic will play out, impacts on the economic, physical, and mental well-being. Again, this type of pandemics has a domino effect which affects the life of marginal people working as self-employed, part-time basis, least well-paid, and in informal work environments.

The $2 \mathrm{I}^{\text {st }}$ century has been the witness of fear from SARS coronavirus in 2002 and further from influenza H5NI in 2003, originated in Hong Kong. However, the $2 \mathrm{I}^{\text {st }}$ century had a bitter pandemic situation for the first time in 2009 with a novel influenza virus, preceded with the emergence of another deadly virus, MERS-CoV in 2012 originated in the Middle East. 
In the eve of the first decade of the 2Ist century, several numbers of pneumonia cases appeared in Wuhan, Hubei, China. After the analysis of the viral genome sequence, a novel coronavirus named SARS-CoV-2 was identified from an unknown source (Biswas et al., 2020). The World Health Organization (WHO) named the disease 'COVID-I9' and declared it a pandemic on March II, 2020 (Sohrabi et al., 2020).

On the other hand, Bangladesh found the presence of COVID I9 for the first time on 8 March 2020 with three persons having corona virus-positive. Among them, two were Italy inpatriate and one was a relative of a returnee. On the IIth day of the country's first coronavirus case, a person of 70 years old passed away on March I8, 2020 (Moin, Sakib, Araf, Sarkar, \& Ullah, 2020). The transmission rate is increasing exponentially and exceeded 20\% steep rise in cases (Khan, 2020). With a rank of 8th in a weekly increase in new coronavirus cases and a high mortality rate of 2.99 percent, Bangladesh stood at the third position in June 2020 in South Asia after India and Pakistan in terms of cases and deaths.

Bangladesh's government has taken steps to flatten the curve of the infection, with the forced lockdown of the transportation system of all kinds, closure of the educational, financial, government, the semi-government institutions-except entity to maintain the necessity of life (Moin et al., 2020). One additional month of the pandemic will cost 2.5-3\% of the global GDP (Fernandes, 2020). In line with the global economy, all sectors including Industry, commerce, agriculture, importexport, employment level, education, and remittance of Bangladesh experienced and is experiencing intense negative impact due to COVID I9 (Shimanta, Gope, \& Sumaiya, 2020).

Though the impacts of COVID I9 seem straightforward, it has a tremendous impact on the life of marginal people. Moreover, 'more than 10 million people are becoming further marginalized due to the loss of wages and jobs in Bangladesh (Bodrud-Doza, Shammi, Bahlman, Islam, \& Rahman, 2020). However, the impact of COVID I9 on the economy at the global and national level, has received attention from the experts. Therefore, it is also significant to explore the impact of COVID I9 at the individual level- with economic, social, mental, cognitive, physical, health safety, uncertainty, and other dimensions and to examine their impact on the life of destitute people.

\section{Literature Review}

Living condition is an amorphous idea that includes more or less everything in life real income, disposable income, consumption, job satisfaction, happiness, and housing. So the standard of living or living conditions can be expressed both in terms of physical and emotional well-being. (Stature, Living Standards, and Economic Development: Essays in ... - AU Komlos - Google Books, n.d.). Many indicators can be applied to measure the standard of living at an individual as well as group level. Indicators of the standard of living at household level may include income, expenditure, years of schooling, and available services (energy supply, transportation, excess to health service) from the community, housing quality, and nutritional food for the members of the family (Nubé, Asenso-Okyere, \& Van Den Boom, 1998).

COVID I9 has affected both individual and whole society across socio-economic dimensions. It has altered the pattern of daily life. Uncertainties about the future, losing a job, losing the near and dear, confined to own home, and restriction of social contacts have affected the mental health of the people (Javakhishvili et al., 2020). The nationwide lockdown mitigated all economic activities (Talukder et al., 2020). Blue color workers who used to work in the RMG industry are moving toward new occupations after losing their jobs. But due to the economic crisis, they are unable to manage new work and to support their dependents (Ahmed, 2020). As a result, of COVID 19, 6 core people could fall into extreme poverty, the World Bank has already warned. As the pandemic has impacted on the family income, child labor is being encouraged in the country (Hossain, 2020). The influence of COVID I9 on the livelihoods of marginal people is not difficult to visualize (Uddin et al., 2020). With a study on 1,066 respondents and rigorous statistical analysis, it was found that the socio-economic crisis of the pandemic fuels the suffering of poor communities by affecting income level, the price hike of essentials, mental stress, and psychosocial wellbeing (Bodrud-Doza et al., 2020).

The measures of the Bangladesh government to mitigate the negative impact of COVID I9 on the economy were timely action. To ensure food security, the authority announced a stimulus package of approximately USD 589 million into the agricultural sector, approximately USD 589 million to give subsidy to farmers, loan facility of approximately USD 3,529 million into industries and service sector, and four more packages for the different sector (Talukder et al., 2020). To address the problems of needy people government initiated the 'Rice for TK IO per KG' and relief program throughout the country. It is a matter of sorrow that misappropriation of relief materials was out of control. Though the top management took action against the irregularity, regular 'social safety net program' and distribution of relief programs was questionable (Asjad, 2020).

According to the definition of the World Health Organization (WHO), mental health is the state of wellbeing in which a person can realize his ability to cope with normal life stressors and utilize competencies to support dependents and community (Khan, 2020). According to the theory of Abraham Maslow, the basic need is the most important thing. The want of food, want of work, and want of safety and security can create psychological disorders and affect mental health. Due to 
COVID I9, a huge number of destitute including micro-business owners, laborers, transport workers, informal sector employees who depend on daily earning have no social security and adequacy of basic needs, Rashid, Theobald, \& Ozano, 2020). BRAC, the largest non-government organization in Bangladesh, surveyed COVID-I9. The survey result found I4 percent have no food reserved at home and 29 percent of the respondents have one to three days of food reserved. Further, extreme poverty had risen by 60 percentage points and poverty by 54 percentage points among the respondents (bdnews 24,2020 ). There is a positive correlation among economic recession, unemployment, and poverty which again are correlated with acute psychological problems leading to suicidal behaviors (Bantjes et al., 2019). Besides, mental health can create suicidal behaviors among some individuals (Bhuiyan, Sakib, Pakpour, Griffiths, \& Mamun, 2020).

There is no remedy for stopping the virus. To fight against corona, the whole world is approaching the diagnosis of the suspect, ensuring quarantine, isolation, and augmenting awareness. Among them, testing has become the most important. Diagnosis tests of corona conducted by IEDCR and other 42 institutions are not enough for the total population in Bangladesh (Moin et al., 2020). On April I8, 2020, Bangladesh tested only 124 tests per million of its population (Maswood, 2020). But the rate of testing increased toI3I3 per million on 22 May 2020. On the other hand, the cycle time of testing is not up to the mark. The imposed fee to test corona, Tk 200 at the booth, and $\mathrm{Tk} 500$ for home service, would discourage some section to test and explore the actual situation as opined by Nazrul Islam, (DW.com2020). Moreover, general people are worried about health safety and security because of recent COVID-I9 testing scam in Bangladesh (bdnews24, 2020).

From the literature review, it is clear and crystal that COVID I9 has impacted negatively on different dimensions at the grass-root level with a long term socioeconomic consequence. But, the human impact of COVID I9 may be more intense in the life of destitute people. Therefore, this is significant to understand the phenomenon so that appropriate measures can be traced out to mitigate the present as well as the future impact of such pandemic on the life of a vulnerable group. Now question arise. What are those factors influenced by COVID I9 in the life of destitute people in Bangladesh? How can these factors affect the life of destitute people by altering consumption patterns, excess to health, education, earning source, financial position, social relation, and overall happiness?

\section{Objectives of the Research}

The core objective of this research was to explore the impact of COVID I9 on the life of destitute people in Bangladesh. To attain the core aim, the following specific objectives were addressed.

- To find out the key factors influenced by COVID I9 at the individual level in Bangladesh.

- To explore the negative impact of COVID I9 on the life of destitute people.

- To explore the association between factors and impact of COVID I9 on destitute people.

\section{Research Methodology}

The paper was based on a quantitative approach in which the authors quantified the phenomenon by counting responses. The procedure followed and resources utilized by authors have been mentioned in the following.

\section{I Sources and Technique of Data Collection}

The study was based on both primary and secondary data. The literature review which was based on newspapers, websites, and journals provided the major portion of secondary data. The authors administrated a field survey using a structured questionnaire to collect primary data from the target people.

\subsection{Population and Sampling Design}

The population of the study was destitute people who belong to the lower ladder in socioeconomic status including employees who work in an informal work environment, unemployed, peasant, Ricksha puller, maidservant, RMG employees, Hokers, day labors, and small business owners. To conclude the population, the authors selected a sample size of 250 from two divisions of Bangladesh- Dhaka, and Mymensingh.

\subsection{Instrument Design, Measurement and Reliability}

The questionnaire was developed into three parts. The first part collected demographic information of the respondents including gender, age range, marital status, employment status, family size, number of earning members in the respondents' family, and occupation. In the second part of the questionnaire, questions were comprised to collect information to find out factors influenced by COVID I9. The authors included 25 items in part two and questions were based on perception, present situation, literature review, and pre-pilot testing interview with the target group. Finally, part three of the questionnaire collected information to assess the perceived negative impact of COVID I9 on the life of destitute people. This section included IO 
questions reflecting both tangible and intangible aspects of life which were developed from the 'Living Standards 2012 questionnaire'. Items addressed the degree to which COVID I9 impacted on overall happiness, mental health, ability to purchase enough goods and service, perceived family condition comparing with the neighbor, financial status, Stability of income source, support from relatives or overall relationship, excess to health services, education of family members and overall hardship in life during the pandemic. The questionnaire was reviewed by experts and the authors mended the questionnaire before the pilot study on 25 respondents. The authors deployed 5 points linear scale to measure respondents' responses. The researchers worded the questions in such a manner that I indicated no impact of COVID I9 at all, 2 indicated a little impact, 3 indicated moderate level impact, thus 4 very much and 5 extreme level impact of COVID I9 on the specific aspect. The result of the pilot study was used to check the reliability and the authors found Cronbach's Alpha $(\alpha)$.7I6 on I0 items of part three and alpha ( $\alpha)$ $.84 \mathrm{I}$ on 25 items of part two for factor analysis. So internal consistency of the scale was found to be excellent according to (Cronbach, I95I; Suriani et al., 2012).

\subsection{Technique and Tools of Data Analysis}

The researchers analyzed primary data with the help of SPSS version 22. To identify the factors influenced by COVID I9 in the life of destitute people, the paper deployed factor analysis (principal component method) with the second part of the questionnaire. With the third part of the questionnaire, researchers calculated the impact of COVID I9 on the life of destitute people based on the mean value and standard deviation of the ten tangible and intangible aspects of life which was adopted from the 'Living Standards 2012 questionnaire'. The authors adopted descriptive statistics to get inside into demographic information and the impact of COVID 19 on the life of destitute people. Finally, the authors to know the association or relationship between factors influenced by COVID I9 and the impact of COVID I9 on the life of destitute people applied multiple regressions. Thus, Independent variables of the study derived from factor analysis, dependent variable- the impact of COVID I9 on the life of destitute people, and two control variables- family size and the number of earning members of the respondents formed the following framework (Figure I) for regression analysis.

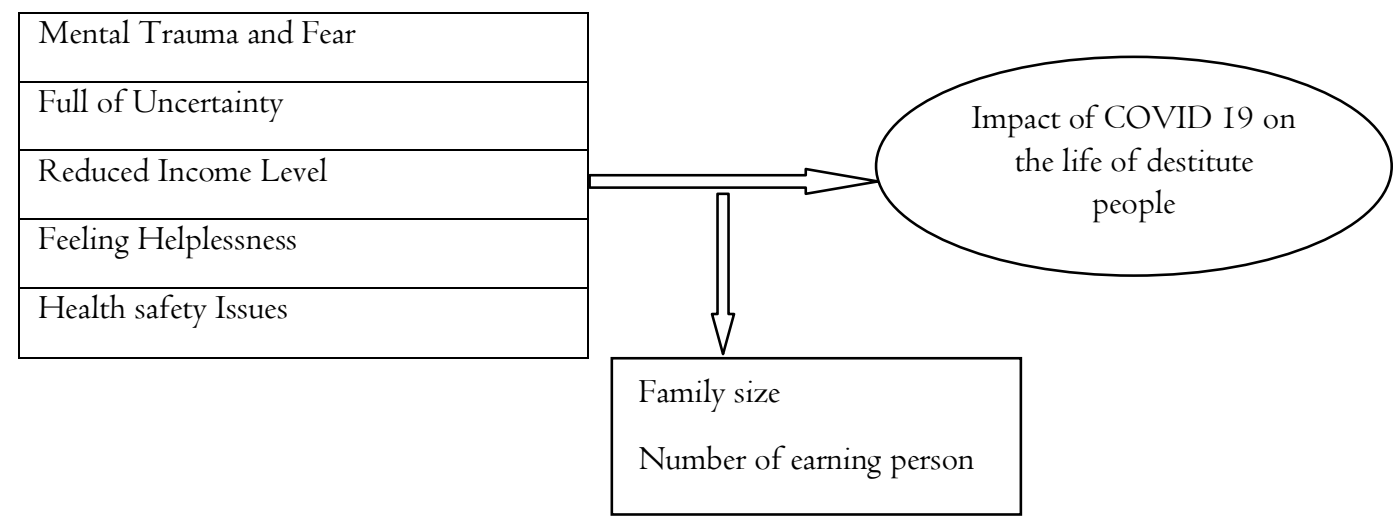

Figure I. Conceptual Framework

\section{Results and Discussion \\ 5.I Demographic Information of the Respondents}

The authors present in this section the demographics information of the respondents with frequency and percentages. Table I illustrates the demographic information according to variable gender, age range, marital status, employment status, family size, earning member, and occupation. Regarding gender, the study comprises $73.6 \%$ male, $23.2 \%$ female, and $3.2 \%$ common gender. The age of the respondents was ranging from 20-60 and authors observe that 36.4\% fall in the age group 20-30, $38.0 \%$ between $30-40$, $17.6 \%$ between age group $40-50$ and only $8.0 \%$ falls between age group 50-60. Among the sample studied $78.8 \%$ was found to be married and $21.2 \%$ was single. Family size indicates the total number of members of respondents and earning member is total persons who earn for the family. The total family size of the sample studied was I 98 and family size for each respondent was ranging from 2 to II. But most samples found to have a family size between 3 and 6.I6.8\% sample have 3 members, 26.8\% have 4, 24.4\% have 5 and $14.0 \%$ have 6 family members. On the other hand, $60.4 \%$ of people said that their family depends on only one person, $34.0 \%$ family depend on 2, and the rest part of the sample $5.6 \%$ had 3 earning person. The researchers purposefully included samples belonging to the marginal group and working in an informal, 
unstable work environment. It was observed that $14.8 \%$ of respondents were unemployed and $85.2 \%$ involved in different types of occupations. $18.4 \%$ of respondents were RMG employees, $6.4 \%$ were peasant, $5.6 \%$ respondents depend on Ricksha to manage their family, $8.0 \%$ were from private service holders and Maidservant was $4.8 \%$ of the respondents. Again, $16.0 \%$ were small business owners and I5.2\% day labor who depend on daily earning to manage bread and butter. Finally, 6.0\% were Hockers who sell their product in the footpath, and $19.6 \%$ falls in other categories. The other category includes people who have no job currently and have lost their earning source during this pandemic and unemployed searching for jobs.

Table I. Demographics information of the 250 respondents

\begin{tabular}{|c|c|c|c|c|c|c|}
\hline \multicolumn{3}{|l|}{ Demographics factors } & \multicolumn{2}{|c|}{ Frequency } & \multicolumn{2}{|c|}{ Percentage } \\
\hline \multirow[t]{3}{*}{ Gender } & \multicolumn{2}{|l|}{ Male } & \multicolumn{2}{|c|}{ I84 } & \multicolumn{2}{|c|}{$73.6 \%$} \\
\hline & \multicolumn{2}{|c|}{ Female } & \multicolumn{2}{|c|}{58} & \multicolumn{2}{|c|}{$23.2 \%$} \\
\hline & \multicolumn{2}{|c|}{ Common gender } & \multicolumn{2}{|c|}{8} & \multicolumn{2}{|c|}{$3.2 \%$} \\
\hline \multirow[t]{4}{*}{ Age } & \multicolumn{2}{|c|}{$20-30$ years } & \multicolumn{2}{|c|}{$9 \mathrm{I}$} & \multicolumn{2}{|c|}{$36.4 \%$} \\
\hline & \multicolumn{2}{|l|}{$30-40$ years } & \multicolumn{2}{|c|}{95} & \multicolumn{2}{|c|}{$38.0 \%$} \\
\hline & \multicolumn{2}{|l|}{$40-50$ years } & \multicolumn{2}{|c|}{44} & \multicolumn{2}{|c|}{$17.6 \%$} \\
\hline & \multicolumn{2}{|l|}{$50-60$ years } & \multicolumn{2}{|c|}{20} & \multicolumn{2}{|c|}{$8.0 \%$} \\
\hline \multirow[t]{2}{*}{ Marital status } & \multirow{2}{*}{\multicolumn{2}{|c|}{$\begin{array}{l}\text { Married } \\
\text { Unmarried }\end{array}$}} & \multicolumn{2}{|c|}{197} & \multirow{2}{*}{\multicolumn{2}{|c|}{$\begin{array}{l}78.8 \% \\
21.2 \% \\
\end{array}$}} \\
\hline & & & 5 & & & \\
\hline \multirow[t]{5}{*}{ Family size } & 2 persons & I0 & $4.0 \%$ & 7 persons & $2 \mathrm{I}$ & $8.4 \%$ \\
\hline & 3 persons & 42 & $16.8 \%$ & 8 persons & IO & $4.0 \%$ \\
\hline & 4 persons & 67 & $26.8 \%$ & IO persons & 2 & $0.8 \%$ \\
\hline & 5 persons & $6 I$ & $24.4 \%$ & I I persons & 2 & $0.8 \%$ \\
\hline & 6 persons & 35 & $14.0 \%$ & & & \\
\hline Employment status & Employed & & & {$[3$} & 85. & \\
\hline & Unemployed & & & & $\mathrm{I} 4$. & \\
\hline Earning member per family & I person & & & $5 \mathrm{I}$ & 60. & \\
\hline & 2 persons & & & & 34. & \\
\hline & 3 persons & & & & 5.6 & \\
\hline Occupation & Rickshaw pu & & & & 5.6 & \\
\hline & Garment em & oyees & & & I8. & \\
\hline & Maidservant & & & & 4.8 & \\
\hline & Small busine & owners & & & I6. & \\
\hline & Private servic & holders & & & 8.0 & \\
\hline & Farmers & & & & 6.4 & \\
\hline & Day labors & & & & I5. & \\
\hline & Hockers & & & & 6.0 & \\
\hline & Others & & & & 19. & \\
\hline
\end{tabular}

Source: Own survey data

\subsection{The Factors Influenced by COVID I9 in the Life of Destitute People}

Factor analysis (Principal component) is a multivariate method that helps the researchers to find variables moving consistently together (Hadi, Abdullah, \& Sentosa, 2016). These variables form components or factors which convey underlying constructs and represent more than a single variable (Cornish, 2007). The generated factors from factor analysis create a new dimension "that can be visualized and measurement variables can be plotted" (Field, 2000). Factor scores from factor analysis can be used as new scores in multiple regression and factor loadings express the importance of a particular variable to a factor (Field, 2000; Horn, 2007). The authors have conducted factor analysis (principal component) to reduce the original variables and find out some latent components to make interpretation easy and vivid. 


\subsection{Usefulness of Data for Factor Analysis}

Table 2. KMO and Bartlett's Test

\begin{tabular}{lll}
\hline Kaiser-Meyer-Olkin Measure of Sampling Adequacy. & .774 \\
\hline Bartlett's Test of Sphericity & Approx. Chi-Square & 3485.517 \\
\cline { 2 - 3 } & $\mathrm{df}$ & $2 \mathrm{I0}$ \\
\cline { 2 - 3 } & Sig. & .000 \\
\hline
\end{tabular}

Table (2) shows KMO and Bartlett's test of sphericity. Kaiser-Meyer-Olkin measures the sample adequacy and Bartlett's measure tests the null hypothesis that the original correlation matrix is an identity matrix. According to Kaiser (I974), $\mathrm{KMO}$ values greater than 0.5 is acceptable and a value closer to I indicates that factor analysis would produce reliable factors. From table I KMO value for sample, adequacy is .774 which falls in the good category as defined by Kaiser (I974) for factor analysis (Hutcheson \& Sofroniou,I999; Hadi et al., 2016). Again, the approximate Chi-square value in Bartlett's test is 3485.517 with a 210 degree of freedom and it is significant at a 95\% level of confidence. Bartlett's test $(p<0.00 \mathrm{I})$ evinces that a linear combination present in the data set and acceptable for further analysis to find out factors influenced by COVID I9 at the individual level.

\subsubsection{The Communality Test}

Table 3 represents the results of communalities in the data set. The communalities portrayed the percent of the variance in each variable which would be explained by the retained factors after extraction. A value of a variable in extraction column (see table 2) closer to $I$ is preferable but value more than 0.5 is an acceptable and low value of a variable such as 0.3 indicates that the variable does not fit with another variable in the component (Hadi et al., 2016). For the given data set no variable was found to have communality value less than 0.5 . 4 variables with communality value, less than 0.5 were excluded from the analysis. Finally, 2I variables (see table 3 ) have communality value ranging from .508 to .894 which indicates the viability of the analysis.

Table 3. Communalities

\begin{tabular}{lll}
\hline & Initial & Extraction \\
\hline ITI: & 1.000 & .857 \\
\hline IT2: & 1.000 & .894 \\
\hline IT3: & 1.000 & .508 \\
\hline IT4 & 1.000 & .647 \\
\hline HI: & 1.000 & .657 \\
\hline H2 & 1.000 & .586 \\
\hline H3: & 1.000 & .782 \\
\hline H4: & 1.000 & .564 \\
\hline MTFI: & 1.000 & .746 \\
\hline MTF2: & 1.000 & .798 \\
\hline MTF3: & 1.000 & .800 \\
\hline MTF4: & 1.000 & .798 \\
\hline MTF5 & 1.000 & .719 \\
\hline MTF6 & 1.000 & .732 \\
\hline HSCI & 1.000 & .673 \\
\hline HSC2: & 1.000 & .791 \\
\hline HSC3 & 1.000 & .582 \\
\hline FUNI & 1.000 & .753 \\
\hline FUN2 & 1.000 & .698 \\
\hline FUN3: & 1.000 & .764 \\
\hline FUN4: & 1.000 & .753 \\
\hline Extraction Method: Principal Component Analysis. & \\
\hline
\end{tabular}




\subsubsection{Factor extraction \& Retention}

Table 4 shows the eigenvalues related to each variable before extraction, after extraction, and after rotation. As eigenvalues must be equal to total variables input, the table is showing 2I linear components. According to ' Eigenvalue rules or the Kaiser's criteria' The authors can retain components with an Eigenvalue larger than I (Hadi et al., 2016). The first component has eigenvalue 6.260, the second component 3.407, third component I.964 and can explain 29.81\%, 16.22\%, and 9.35\% variance of the data set respectively. So the components tend to decrease in variance explanation in downstream. This is happening because of the relative importance of the component according to eigenvalues. However, 5 components together explain 7I.92\% variance before and after extraction. The 'Rotation Sums of Squared Loadings' column is showing only components that have eigenvalues more than one but the relative importance of the component has been redistributed and equalized through the varimax rotation. Now component I can explain 22.52\% variance, component 2 can explain I3.63\%, and component 3 can explain $13.59 \%$ variance. Thus 7I.92\% variance of the data set has been redistributed over 5 extracted components.

Table 4. Total Variance Explained

\begin{tabular}{|c|c|c|c|c|c|c|c|c|c|}
\hline \multirow[t]{2}{*}{ Component } & \multicolumn{3}{|c|}{ Initial Eigenvalues } & \multicolumn{3}{|c|}{$\begin{array}{c}\text { Extraction Sums of Squared } \\
\text { Loadings } \\
\end{array}$} & \multicolumn{3}{|c|}{$\begin{array}{c}\text { Rotation Sums of Squared } \\
\text { Loadings } \\
\end{array}$} \\
\hline & Total & $\begin{array}{c}\% \text { of } \\
\text { Variance }\end{array}$ & $\begin{array}{c}\text { Cumulative } \\
\% \\
\end{array}$ & Total & $\begin{array}{c}\% \text { of } \\
\text { Variance }\end{array}$ & $\begin{array}{c}\text { Cumulative } \\
\% \\
\end{array}$ & Total & $\begin{array}{c}\% \text { of } \\
\text { Variance }\end{array}$ & $\begin{array}{c}\text { Cumulative } \\
\% \\
\end{array}$ \\
\hline $\mathrm{I}$ & 6.260 & 29.808 & 29.808 & 6.260 & 29.808 & 29.808 & 4.730 & 22.525 & 22.525 \\
\hline 2 & 3.407 & 16.222 & 46.031 & 3.407 & 16.222 & 46.031 & 2.863 & $\mathrm{I} 3.634$ & 36.159 \\
\hline 3 & 1.964 & 9.352 & 55.383 & 1.964 & 9.352 & 55.383 & 2.855 & 13.594 & 49.752 \\
\hline 4 & 1.825 & 8.693 & 64.075 & 1.825 & 8.693 & 64.075 & 2.534 & 12.065 & 61.817 \\
\hline 5 & 1.648 & 7.849 & 71.924 & 1.648 & 7.849 & 71.924 & 2.122 & I0.107 & 71.924 \\
\hline 6 & .881 & 4.195 & 76.119 & & & & & & \\
\hline 7 & .764 & 3.637 & 79.756 & & & & & & \\
\hline
\end{tabular}

\subsubsection{Scree Plot}

Another technique to retain components is the scree plot test (Cattell, 1966; Hadi et al., 2016). According to Catell criteria, factors above the elbow should be retained. The (Figure 2) is showing a slope between the eigenvalues and $2 \mathrm{I}$ variables. From the scree plot, it is clear that 5 components have an eigenvalue greater than I. From the components 6 to 2I, there is a flat line. Finally from the Kaiser's rule and scree plot, the researchers have retained 5 components.

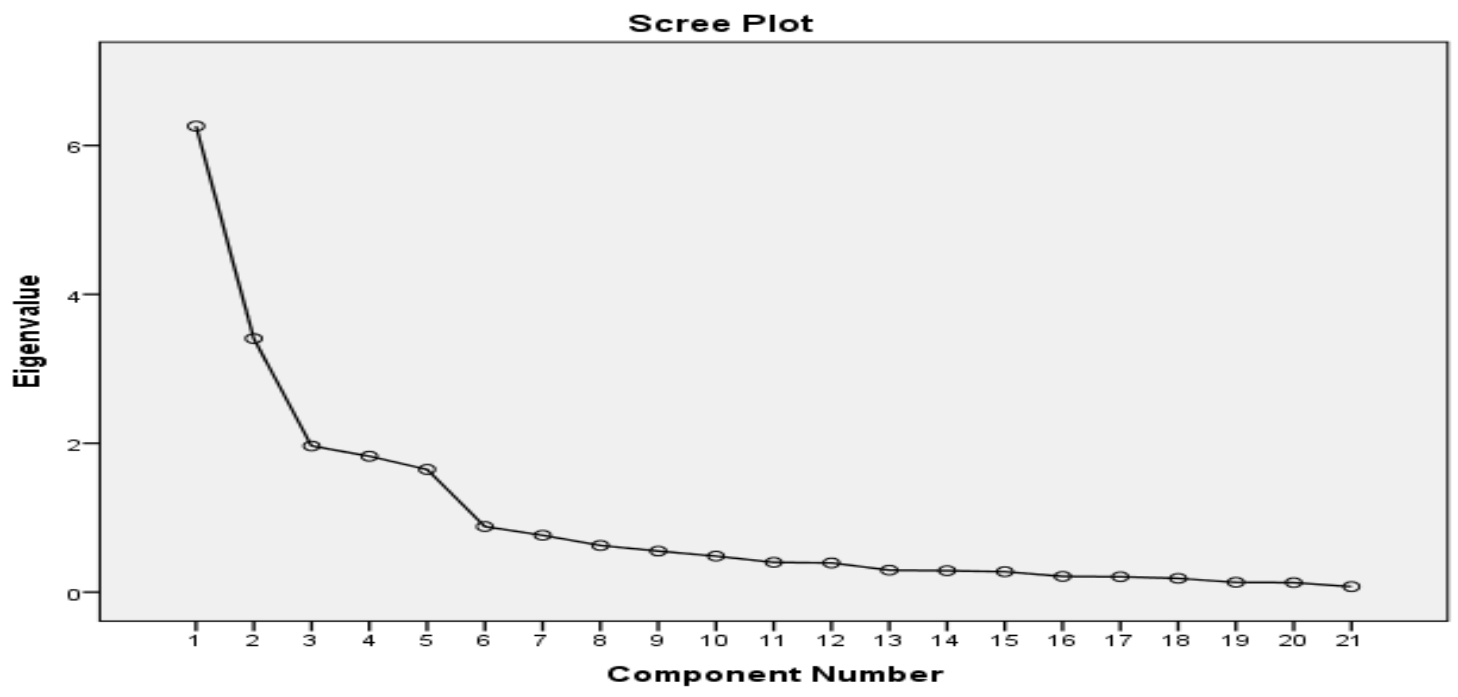

Figure 2. The Scree Plot 


\subsubsection{Rotated Component Matrix}

Table 5 is showing the rotated component matrix. In the matrix, rotation alters the pattern of the factor loadings and makes the component matrix simple, easy, and interpretable. The authors used the orthogonal-varimax technique assuming that there is no relationship among the extracted components and ignored the loadings value less than 0.35 . The rotated component matrix shows that component I comprises 6 items with loading ranging from .825 to .884 . The items in component I are MTF4, MTF2, MTF3, MTFI, MTF5 and MTF6. Component 2 has loaded with 4 items, with factor loading ranging from .708 to .83I. Items included in component 2 are FUN3, FUN4, FUN2, and FUNI. Component 3 has 4 items, IT2 with loading .938, ITI with loading .908, IT4 with loading.728, and IT3 with loading .626. Component 4 has loaded with 4 items, with factor loading ranging from .722 to .868. Items of component 4 are H3, HI, H4, and H2. The last one, component 5 has loaded with 3 items with loading ranging from .728 to .878 . The items are HSC2, HSC3, and HSCI.

Table 5. Rotated Component Matrix

\begin{tabular}{|c|c|c|c|c|c|}
\hline & \multicolumn{5}{|c|}{ Component } \\
\hline & $\mathrm{I}$ & 2 & 3 & 4 & 5 \\
\hline MTF4 & .884 & & & & \\
\hline MTF2 & .869 & & & & \\
\hline MTF3 & .864 & & & & \\
\hline MTFI & .854 & & & & \\
\hline MTF5 & .826 & & & & \\
\hline MTF6 & .825 & & & & \\
\hline FUN3 & & $.83 I$ & & & \\
\hline FUN4 & & .818 & & & \\
\hline FUN2 & & .800 & & & \\
\hline FUNI & & .708 & & & \\
\hline IT2 & & & .938 & & \\
\hline ITI & & & .908 & & \\
\hline IT4 & & & .728 & & \\
\hline IT3 & & & .626 & & \\
\hline $\mathrm{H} 3$ & & & & .868 & \\
\hline $\mathrm{HI}$ & & & & .747 & \\
\hline $\mathrm{H} 4$ & & & & .734 & \\
\hline $\mathrm{H} 2$ & & & & .722 & \\
\hline HSC2 & & & & & .878 \\
\hline HSC3 & & & & & .755 \\
\hline HSCI & & & & & .728 \\
\hline $\begin{array}{l}\text { Extracti } \\
\text { Rotatic }\end{array}$ & $\begin{array}{l}\text { Metho } \\
\text { Method }\end{array}$ & $\begin{array}{l}\text { Princip } \\
\text { /arimax }\end{array}$ & $\begin{array}{l}\text { Compc } \\
\text { with Ka }\end{array}$ & $\begin{array}{l}\text { ent Anal } \\
\text { r Norm }\end{array}$ & $\begin{array}{l}\text { sis. } \\
\text { ization. }\end{array}$ \\
\hline Rotatio & onverge & n 6 ite & tions. & & \\
\hline
\end{tabular}

\subsubsection{Labeling the components}

Factor analysis has explored 5 components. According to table 6, the first component has 6 variables that have a high correlation among them. MTF4 with factor loading .884, MTF2 with factor loading .869, MTF3 with factor loading .864, MTFI with factor loading .854, MTF5 with factor loading .826, and MTF6 with factor loading .825 are consistently moving together. These 6 items are measuring the same construct related to fear, mental pressure, discomfort, worried from COVID I9. So the researcher can label Mental Trauma and Fear as the first component which can alone explain $22.52 \%$ variance in the data set. Component 2 is moving with four variables FUN3, FUN4, FUN2, and FUNI. These variables have correlation ranging from .708 to $.83 \mathrm{I}$ and measuring uncertainty about earning source, alternative income source, stable family condition, and future uncertainty arising from COVID I9 situation. So component 2 can be labeled as Full of Uncertainty which can explain the variance of $13.63 \%$ of the data set. The next component is moving together with four variables (IT2, ITI, IT4, IT3) with correlation ranging from .626 to .938. These items measuring the same construct by counting change in income, adequacy of current income to maintain livelihood, and support the family during the COVID I9 crisis. The common thing here is the 
change in income level because of which people are facing difficulties in maintaining a sounds life. Hence, component 3 can be named as Reduced Income Level which explains 13.59\% variance. Component 4 has loaded with four items including H3, HI, $\mathrm{H} 4$, and $\mathrm{H} 2$. With correlation ranging from .722 to .868 , these items consistently moving together and measuring the degree to which destitute people are receiving assistance from a different entity during the pandemics, the degree to which they are feeling helpless. Therefore component 4 can be called Feeling Helplessness which can explain I2.I\% variance. Last but not the least, component 5 is moving with 3 variables which together explain IO.II\% variance. The component measuring observed perception toward availability, efficiency, and difficulty of coronavirus treatment with factor loadings ranging from.728 to .878 . Therefore, component 5 can be labelled as Health safety issues.

Table 6. Labeling the components

\begin{tabular}{|c|c|c|c|}
\hline \multirow[t]{2}{*}{ Component I: Mental Trauma and Fear } & \multicolumn{3}{|c|}{ Variance explain $22.52 \%$} \\
\hline & Mean & Loading & Cronbach's Alpha \\
\hline I feel mental pressure when thinking about coronavirus & 3.12 & .884 & \\
\hline I do not feel comfortable when I think about the corona & 3.30 & .869 & .936 \\
\hline I am afraid to go out because of coronavirus & 3.07 & .864 & \\
\hline I am afraid of coronavirus & 3.24 & .854 & \\
\hline I feel mental stress hearing news of death from coronavirus & 3.62 & .826 & \\
\hline I am worried thinking that corona can take my life. & 3.37 & .825 & \\
\hline \multirow[t]{2}{*}{ Component 2: Full of Uncertainty } & \multicolumn{3}{|c|}{ Variance explain I3.63\% } \\
\hline & Mean & Loadings & Cronbach's Alpha \\
\hline It will be difficult to get new work if I lose my current work & $3.8 \mathrm{I}$ & $.83 \mathrm{I}$ & .866 \\
\hline My family can suffer financially due to this pandemic & 3.86 & .818 & \\
\hline I can lose my earning source due to corona crisis & 3.43 & .800 & \\
\hline I feel insecurity about the future due to corona crisis & 3.62 & .708 & \\
\hline \multirow[t]{2}{*}{ Component 3: Reduced Income Level } & \multicolumn{3}{|c|}{ Variance explain I3.59\% } \\
\hline & Mean & Loadings & Cronbach's Alpha \\
\hline I cannot earn the same as I could before COVID I9 crisis & 3.90 & .938 & .850 \\
\hline My income has decreased due to COVID I9 pandemic & 3.70 & .908 & \\
\hline It is difficult to afford goods and service with my current income & 4.17 & .728 & \\
\hline My income is not enough to support the family during COVID I9 crisis & 3.75 & .626 & \\
\hline \multirow[t]{2}{*}{ Component 4: Feeling Helplessness } & \multicolumn{3}{|c|}{ Variance explain I2.I\% } \\
\hline & Mean & Loadings & Cronbach's Alpha \\
\hline I am not getting assistance from the upper class of the society & 4.37 & .868 & .781 \\
\hline I am not getting financial or mental support from my relatives & 4.15 & .747 & \\
\hline I am feeling helpless during this pandemic & 3.77 & .734 & \\
\hline I am not receiving enough assistance from the government & 3.96 & .722 & \\
\hline \multirow[t]{2}{*}{ Component 5: Health safety issues } & \multicolumn{3}{|c|}{ Variance explain I0.II\% } \\
\hline & Mean & Loadings & Cronbach's Alpha \\
\hline It will not be easy to get medical facility if I affected by corona & $3.8 \mathrm{I}$ & .878 & .737 \\
\hline The authority is not efficient at corona testing and providing the report & 3.37 & .755 & \\
\hline it will be difficult for me to test corona if symptoms appear & 3.32 & .728 & \\
\hline
\end{tabular}

Source: Own survey data

\subsection{Impact of COVID I9 on the General Life of Destitute People}

The impact of COVID 19 on the life of destitute people was measured with ten items including both tangible and intangible indicators. The question was worded in such a way that I indicated no negative impact of COVID I9 on the specific aspect of life, 2 indicated little impact, 3 moderate, 4 very much, and 5 extreme impacts. Thus overall impact was obtained by calculating the mean value of the ten indicators. Table 7 illustrates the result of the respondents. Negative impact on happiness considering everything during the pandemic has a mean value of 3.I5 and SD I.34. The impact on mental health has mean 3.13 and SD 1.34. Excess to goods and services or the ability to purchase needed commodities during COVID I9 has decreased with a mean of 3.40 and SD 1.I6. Perceived happiness with overall family condition comparing with neighbors during this pandemic has mean 2.92 and SD 1.52. Disruption of COVID I9 on the education of family members has a mean 3.35 and SD value I.46. The pandemic has impacted the financial status which causes indebtedness and the crisis in the life of destitute people and with 
mean 2.68 and SD I.44, it seems the impact of COVID I9 on financial status is somewhere between a little and moderate. The observed group found to be worried about not having a stable earning source or job during the crisis with a mean value of 3.42 and an SD value of I.35. The relation dimension among the sample seems to be affected very much. The destitute people are not receiving support from relatives during coronavirus crisis with mean 4.07 and SD I.32. The last but one is the perceived ability to afford health services during the crisis has a mean of 3.78 and I.I2. Finally, the overall hardship in life due to the corona crisis has a mean value of 4.16 and an SD value of I.I6. The last row (see table 7) shows the composite result of all items and the total impact of COVID I9 on the life of destitute people. According to the table, only I4.I5\% of people think that there is no impact of COVID I9 on their life. I I.94\% think that the pandemic has a little impact, I9.05\% opines COVID I9 has a moderate impact, $26.72 \%$ sample agree with very much impact and finally, $28.14 \%$ sample perceive that the pandemic has affected their life extremely. With composite (see the last row from table 33) mean value 3.4056 and SD 0.698 , the authors find evidence that there is a moderate level impact of COVID I9 on the life of destitute people in Bangladesh.

Table 7. Impact of COVID I9 on the life of destitute people

\begin{tabular}{|c|c|c|c|c|c|c|c|}
\hline Items & $\begin{array}{l}\text { Not at } \\
\text { all }\end{array}$ & A little & Moderately & $\begin{array}{l}\text { Very } \\
\text { much }\end{array}$ & Extremely & Mean & $\mathrm{SD}$ \\
\hline Happiness & $16.8 \%$ & $\mathrm{I} 4.4 \%$ & $24.4 \%$ & $26 \%$ & $\mathrm{I} 8.4 \%$ & 3.15 & $\mathrm{I} .34$ \\
\hline Mental health & $\mathrm{I} 2.8 \%$ & $15.2 \%$ & $30.8 \%$ & $28.8 \%$ & $\mathrm{I} 2.4 \%$ & 3.13 & I.I9 \\
\hline Goods and service & $10.4 \%$ & $8.8 \%$ & $27.2 \%$ & $37.6 \%$ & $16 \%$ & 3.40 & I.I6 \\
\hline Family condition & $16.4 \%$ & $16.8 \%$ & $20.4 \%$ & II.6\% & $24.8 \%$ & 2.92 & $\mathrm{I} .52$ \\
\hline Family education & $20 \%$ & $8 \%$ & I6.4\% & $28.4 \%$ & $27.2 \%$ & 3.35 & 1.46 \\
\hline Financial status & $27.2 \%$ & $24.2 \%$ & $18.8 \%$ & $10.8 \%$ & I8.4\% & 2.68 & $\mathrm{I} .44$ \\
\hline Stable income source & $15.2 \%$ & $9.6 \%$ & $16.4 \%$ & $35.2 \%$ & $23.6 \%$ & 3.42 & 1.35 \\
\hline $\begin{array}{l}\text { Support from } \\
\text { relatives/Relationship }\end{array}$ & $\mathrm{I0} \%$ & $5.2 \%$ & $7.6 \%$ & $22 \%$ & $55.2 \%$ & 4.07 & I. 32 \\
\hline Health services & $4.4 \%$ & $10.4 \%$ & $18.8 \%$ & $35.6 \%$ & $30.8 \%$ & 3.78 & I.I2 \\
\hline Hardship in life & $6.4 \%$ & $4.8 \%$ & $7.6 \%$ & $29.2 \%$ & $52.0 \%$ & 4.16 & I.16 \\
\hline Total impact & $14.15 \%$ & I I.94\% & $19.05 \%$ & $26.72 \%$ & $28.14 \%$ & 3.4056 & 0.698 \\
\hline
\end{tabular}

\subsection{Association of Factors with the Impact of COVID I9 on the Life of Destitute People}

To explore the causal relationship between the impact of COVID I9 on the life of destitute people (dependent variable) and 5 factors (from factor analysis) influenced by COVID I9 at the individual level (independent variables), the researchers deployed multiple regression models in this section. In addition to independent variables, researchers included two control variables family size and the number of earning persons assuming that they have a significant influence on the dependent variable. Therefore the following hypothesis was tested.

Null hypothesis Hor: Factors influenced by COVID I9 do not have a relation with the impact of COVID I9 on the life of destitute people.

Alternate hypothesis HAr: Factors influenced by COVID I9 have a relation with the impact of COVID I9 on the life of destitute people.

Model Fit: The model summary table 8 shows the viability of conducting the regression model with 7 predictors of the impact of COVID I9 on the life of destitute people. R-value .820 indicates a good correlation between the dependent and independent variables. Again, the independent variable can explain 67.2\% variance(R Square .672) of the impact of COVID I9 on destitute people. There is a minimum variation between the population and sample result since adjusted $\mathrm{R}$ Square change only .009 from R Square (Jain \& Chetty, 2017).

Table 8. Model Summary

\begin{tabular}{|c|c|c|c|c|}
\hline Model & $\mathrm{R}$ & R Square & $\begin{array}{l}\text { Adjusted } \\
\text { Square }\end{array}$ & $\begin{array}{l}\mathrm{R} \text { Std. Error of the } \\
\text { Estimate }\end{array}$ \\
\hline $\mathrm{I}$ & $.820^{\mathrm{a}}$ & .672 & .663 & $.4058 \mathrm{I}$ \\
\hline $\begin{array}{l}\text { a. Pred } \\
\text { Health } \\
\text { Membe }\end{array}$ & $\begin{array}{l}\text { ors: (C } \\
\text { fety is } \\
\text { Family }\end{array}$ & $\begin{array}{l}\text { ), Mental } \\
\text { educed In }\end{array}$ & $\begin{array}{l}\text { uma and } \\
\text { Level, I }\end{array}$ & $\begin{array}{l}\text {, Feeling Helplessness, } \\
\text { f Uncertainty, Earning }\end{array}$ \\
\hline
\end{tabular}


Again from the ANOVA (See Table 9), it is observed that the P-value is less than 0.05, so there is a statistically significant relationship between the independent variables \& impact of COVID I9 on the life of destitute people at the $95.0 \%$ confidence level. The prediction model F $(7,242)=70.870, \mathrm{p}<.00 \mathrm{I}$, is statistically significant. So there is a probability of rejecting the null hypothesis.

Table 9. ANOVA

\begin{tabular}{|c|c|c|c|c|c|c|}
\hline Model & & Sum of Squares & $\mathrm{df}$ & Mean Square & $\mathrm{F}$ & Sig. \\
\hline \multirow[t]{3}{*}{$\mathrm{I}$} & Regression & 81.698 & 7 & I I.67I & 70.870 & $.000^{\mathrm{b}}$ \\
\hline & Residual & 39.854 & 242 & .165 & & \\
\hline & Total & $\mathrm{I} 2 \mathrm{I} .552$ & 249 & & & \\
\hline \multicolumn{7}{|c|}{ a. Dependent Variable: Impact of COVID I9 on the life of destitute people } \\
\hline
\end{tabular}

The coefficient table shows the result of regression analysis in detail. From the table, the following regression equation of the fitted model has been drawn.

Impact of COVID I9 (YI) $=3.406+0.173^{* *}$ (Reduced Income Level $)+0.189^{*}($ Feeling Helplessness $)+0.195^{* *}$ (Mental Trauma and Fear) $+0.174^{\star}($ Health safety issues $)+0.182^{\star}\left(\right.$ Full of Uncertainty) $+0.102^{\star}$ Family Size $0.082^{*}$ (Earning Member)+ ei.

Constant is the raw score which is denoted as YI intercept. For the given model, it has a value of 3.406. The primary intention of the researchers is to look into the raw $(B)$ and standardized $(\boldsymbol{\beta})$ coefficients and their significance levels have been determined by $t$-tests. Here $B$ indicates impact and $\boldsymbol{\beta}$ measures the relative importance of independent variables.

Table IO. Coefficients ${ }^{\mathrm{a}}$

\begin{tabular}{|c|c|c|c|c|c|c|c|}
\hline & \multirow[t]{2}{*}{ Model } & \multicolumn{2}{|c|}{$\begin{array}{c}\text { Unstandardized } \\
\text { Coefficients }\end{array}$} & \multirow{2}{*}{$\begin{array}{l}\text { Standardized } \\
\text { Coefficients } \\
\text { B }\end{array}$} & \multirow[t]{2}{*}{$\mathrm{t}$} & \multirow[t]{2}{*}{ Sig. } & \multirow[t]{2}{*}{$\begin{array}{l}\text { Hypothesis Testing Result at a } 95 \% \\
\text { confidence interval }\end{array}$} \\
\hline & & $\mathrm{B}$ & $\begin{array}{c}\text { Std. } \\
\text { Error }\end{array}$ & & & & \\
\hline \multirow[t]{8}{*}{ I } & (Constant) & 3.406 & .026 & & 132.689 & .000 & \\
\hline & $\begin{array}{l}\text { Reduced } \\
\text { Income Level }\end{array}$ & .173 & .030 & .248 & 5.869 & .000 & Null hypothesis rejected $(0.00 \mathrm{I}<0.05)$ \\
\hline & $\begin{array}{l}\text { Feeling } \\
\text { Helplessness }\end{array}$ & .189 & .028 & $.27 \mathrm{I}$ & 6.859 & .000 & Null hypothesis rejected $(0.00 \mathrm{I}<0.05)$ \\
\hline & $\begin{array}{l}\text { Mental } \\
\text { Trauma and } \\
\text { Fear }\end{array}$ & .195 & .029 & .279 & 6.669 & .000 & Null hypothesis rejected $(0.00 \mathrm{I}<0.05)$ \\
\hline & $\begin{array}{l}\text { Health safety } \\
\text { issues }\end{array}$ & .174 & .027 & .249 & 6.442 & .000 & Null hypothesis rejected $(0.00 \mathrm{I}<0.05)$ \\
\hline & $\begin{array}{l}\text { Full of } \\
\text { Uncertainty }\end{array}$ & .182 & $.03 \mathrm{I}$ & .260 & $5.9 \mathrm{II}$ & .000 & Null hypothesis rejected $(0.00 \mathrm{I}<0.05)$ \\
\hline & Family Size & .102 & .028 & .146 & 3.653 & .000 & Null hypothesis rejected $(0.00 \mathrm{I}<0.05)$ \\
\hline & $\begin{array}{l}\text { Earning } \\
\text { Member }\end{array}$ & -.082 & .027 &.- .117 & -3.002 & .003 & Null hypothesis rejected $(0.003<0.05)$ \\
\hline & ependent Varia & Impa & OVID & on the life of & stitute $\mathrm{p}$ & & \\
\hline
\end{tabular}

According to table I0, with t value 5.869, 6.859, 6.669, 6.442, 5.9II reduced income level, feeling helplessness, mental trauma, and fear, health safety issues, full of uncertainty have positive influence relation with the impact of COVID I9 which is statistically significant $(\mathrm{P}<0.05)$. Confounding variable family size has a positive significant relationship $(\mathrm{t} 3.653, \mathrm{p}<$ 0.05) with the dependent variable. That's the more the number of a family member the more negative impact of COVID I9. On the other hand, the number of earning members of the family has a negative association with the dependent variable and the relationship is significant with $\mathrm{t}-3.002$ and $\mathrm{P}$-value $(0.003<0.05)$. That's the more the number of earning persons of the family the less negative impact on life is experienced during the pandemic. 


\subsection{Discussion with Findings}

The core aspiration of the paper was to explore the impact of COVID I9 on the life of destitute people in Bangladesh. To attain the mission, the authors addressed three questions. What are the factors influenced by COVID I9 at the individual level? Perceived impact of COVID I9 on the life of destitute people? What is the causal relationship between factors and the impact of COVID I9 on the life of destitute people? The result of the analysis renders the following findings for this paper.

- There are five factors influenced by COVID I9 in the life of destitute people including Mental Trauma and Fear, Full of Uncertainty, Reduced Income Level, Feeling Helplessness and Health Safety Issues;

- Destitute people perceive that there is a moderate (mean 3.406, SD 0.698) negative impact of COVID I9 on their life considering tangible and intangible aspects; And

- There is a statistically significant association between five factors and the impact of COVID I9 on the general life of destitute people with due consideration of confounding variable family size and number of earning members.

The first component is 'Mental Trauma and Fear' which explains the $22.52 \%$ variance of the data set. This component indicates that the observed people are mentally pressurized due to COVID I9. Their comfortable level in life has been decreased. They are so afraid of the coronavirus that they fear to go out of the home. Moreover, death news from the coronavirus creates mental stress and people feel frustration that corona could take their life. This component has an affinity with one of the findings of (Javakhishvili et al., 2020), (Bodrud-Doza et al., 2020) who concluded that COVID I9 creates mental stress and affects mental health and psychosocial wellbeing. The regression result evinces that 'Mental Trauma and Fear' has $19.5 \%$ ability to change on the impact of COVID I9 which is statistically significant $(\mathrm{p}=0.000<0.05)$. Moreover, $\beta .279$ which is based on changes in standard deviation indicates that 'Mental Trauma and Fear' is the most important predictor of the impact of COVID I9 among 5 factors (Zannah, 2017).

The component 2 which explains 13.63\% variance is 'Full of Uncertainty. Everyone wants some degree of certainty of earning source to lead a stable life. COVID I9 has imposed a high degree of uncertainty about earning source in the mind of marginal people. The sample opines that the future seems to be uncertain due to this pandemic. Besides, there is no security of earning from an informal work environment. They may lose their means of earning at any time and it will be difficult to manage new work in such a turbulent situation. Therefore, marginal people found to be worried thinking that they along with their dependants may suffer a lot economically due to COVID I9 crises. This factor has similarities with a report of (Ahmed, 2020) which said blue color workers are moving toward new occupations after losing their jobs. But due to the economic crisis, they are unable to manage new work and to support their dependents. While other factors remain constant, a $\mathrm{I} \%$ change in 'Full of Uncertainty' can change $18.2 \%$ in the impact of COVID I9 on the life of destitute people which is significant $(\mathrm{p}=0.000<$ 0.05). Comparing $\beta .260$ of 'Full of Uncertainty' with other factors, it has position three in terms of being important predictors of the impact of COVID 19 on the population of the study.

Component 3 is 'Reduced Income Level' and it explains $13.59 \%$ variance of the data. The core notion of 'Reduced Income Level' is that the income of the sample population has decreased very much comparing with the income before COVID 19. Therefore, it is very difficult to maintain a balanced livelihood and support the family during the COVID I9 crisis. This component has similarity with the result of the previous study of (Bodrud-Doza et al., 2020) who found that COVID I9 augments the suffering of poor communities by affecting income level, the price hike of essentials, and (Rashid et al., 2020) found that destitute people who depend on daily earning have no social security and adequacy of basic needs because of the pandemic. It can be inferred with B.I73 and $\beta .248$ that 'Reduced Income Level' has a I7.3\% influence on the impact of COVID I9 on the life of destitute people and the prediction is significant at $95 \%$ confidence level $(p=0.000<0.05)$.

Component 4 Feeling Helplessness' explains a 12.1\% variance (Asjad, 2020) reported that programs taken by the Bangladesh government to mitigate the sufferings of destitute people during the pandemic were subject to misappropriation and questionable. Besides assistance from the government, Feeling Helplessness' also measures the degree to which destitute people are getting financial and mental support from relatives and people who belongs to the upper class of the society. Destitute people in Bangladesh are feeling helpless during the pandemic considering the assistance they are getting from a different entity. The regression result suggests that the component 'Feeling Helplessness' has significant influence $(p=0.000<0.05)$ and can change (B I8.9\%) of the impact of COVID I9 on the life of destitute people. Moreover, 'Feeling Helplessness' is the second most important predictor $(\beta .27 \mathrm{I})$ of the impact of COVID I9 in terms of standard deviation change in the sample studied. Finally the last one, component 5 is 'Health safety issues' influenced by COVID I9 and this component was found to be an explainer of IO.II\% variance among the five components. This component conveys the perception of destitute people toward health services available for COVID I9 in Bangladesh. Their perception is that it is very difficult to test corona and the health system is not efficient at corona testing and providing reports. Moreover, destitute people do not think that it will be easy to get a 
medical facility if affected by COVID I9. 'Health safety issues' have a significant influence on the impact of COVID I9 on the life of destitute people and can bring a change of $19.5 \%$ when other variables remain constant and the prediction is significant with a confidence level of $95 \%(p=0.000<0.05)$.

\section{Conclusion}

There are five factors influenced by COVID I9 at the individual level 'Mental Trauma and Fear', Full of Uncertainty', 'Reduced Income Level', 'Feeling Helplessness', and 'Health Safety Issues'. Considering tangible and intangible aspects, COVID I9 has brought a moderate impact on the life of destitute people in Bangladesh. This paper found a significant relation of the 5 factors with the overall impact of COVID I9 with due consideration of the influence of confounding factors family size and the number of earning members. It is not possible to manipulate family size, the number of earning persons, and other confounding factors. But the responsible authority can look at the factors found here to develop and implement efficient programs especially for the marginal group. Again, this paper found that among the 5 factors, 'Mental Trauma and Fear' is the most important predictor of the impact of COVID I9 which is followed by 'Feeling Helplessness' and 'Full of Uncertainty'. It seems the pandemic affects mostly the inner state of people and the problem cannot be addressed easily. The government with responsibility and the upper class of the society with humanity should stand beside the marginal people. Besides financial support, creating a platform at the root level through appropriate media is the demand of situation to ensure creating awareness, mental support, the resistance of misinformation, the guideline to make available treatment for destitute people. In fine, the cogitation of these factors may help mitigate the negative impact of COVID I9 on the life of destitute people in a developing country, especially in Bangladesh.

\section{References}

Ahmed, S. (2020, July II). Rickshaw pullers in crisis, Bangla version. https://www.kalerkantho.com/print-edition/lastpage/2020/07/I I/933393?fbclid=IwARI3JEhyzZEP6_KUlAaFv2YohFXeExhTXn5TeSkSrFODRiNmIGQUF TuryLO

Asjad, T . (2020). Unacceptable irregularities in relief operation. Retrieved from https://thefinancialexpress.com.bd/views/unacceptable-irregularities-in-relief-operation-I587I40905

Bantjes, J., Iemmi, V., Coast, E., Channer, K., Leone, T., McDaid, D., . . . Lund, C. (2016). Poverty and suicide research in lowand middle-income countries: Systematic mapping of literature published in English and a proposed research agenda. Global Mental Health, 3, E32. doi:10.1017/gmh.2016.27

Bhuiyan, A. K. M. I., Sakib, N., Pakpour, A. H., Griffiths, M. D., \& Mamun, M. A. (2020). COVID-I9-Related Suicides in Bangladesh Due to Lockdown and Economic Factors: Case Study Evidence from Media Reports. In International Journal of Mental Health and Addiction (pp. I-6). Springer. https://doi.org/I0.I007/s I I469-020-00307-y

Biswas, A., Bhattacharjee, U., Chakrabarti, A. K., Tewari, D. N., Banu, H., \& Dutta, S. (2020). Emergence of Novel Coronavirus and COVID-19: whether to stay or die out? Critical Reviews in Microbiology, 46(2), I82-193. https://doi.org/I0.I080/I04084IX.2020.I73900I

Bodrud-Doza, M., Shammi, M., Bahlman, L., Islam, A. R. M. T., \& Rahman, M. M. (2020). Psychosocial and Socio-Economic Crisis in Bangladesh Due to COVID-I9 Pandemic: A Perception-Based Assessment. Frontiers in Public Health, 8 (June). https://doi.org/I0.3389/fpubh.2020.0034I

Bdnews24. (2020, April). BRAC survey finds I4pc of low income people do not have food at home during shutdown, Available: https:// bdnews24. com/ economy/2020/ 04/ I0/ brac- survey- finds- I4pc- of- low- income- peopledo- not- have- food- at- home- during- shutdown

Cornish, R. (2007). Statistics : 3 . 3 Factor Analysis. Analysis, 3-5.

Cronbach, L. J. (I95I). Coefficient alpha and the internal structure of tests. psychometrika, I6(3), 297-334.

Cattell, R. B. (1966). The scree test for the number of factors. Multivariate behavioral research, I(2), 245-276.

Fernandes, N. (2020). Economic Effects of Coronavirus Outbreak (COVID-I9) on the World Economy. Available at SSRN: https: / / ssrn.com/abstract $=3557504$

Field, T. (2000). Touch therapy. Elsevier Health Sciences.

Horn, R. (2007). Exploratory Factor Analysis. Analysis, I904(Darlington), I8. https://doi.org/I0.1007/0-387-27604-I_I5

Hossain, M. K. (2020, Jun 24) Covid-I9-Increasing the risk of child labor? Retrieved from jaijaidinbd.com, Bangla version

Hutcheson, G. D., \& Sofroniou, N. (1999). The multivariate social scientist: Introductory statistics using generalized linear models. Sage.

Hadi, N. U., Abdullah, N., \& Sentosa, I. (2016). An easy approach to exploratory factor analysis: Marketing perspective. Journal of Educational and Social Research, 6(I), 215. https://doi.org/I0.590I/jesr.2016.v6nIp2I5

Javakhishvili, J. D., Ardino, V., Bragesjö, M., Olff, M., Schäfer, I., Darejan, J., Ardino, V., Bragesjö, M., Javakhishvili, J. D., Ardino, V., Bragesjö, M., \& Olff, M. (2020). Trauma-informed responses in addressing public mental health 
consequences of the COVID-I9 pandemic : position paper of the European Society for Traumatic Stress Studies ( ESTSS ) consequences of the COVID-I9 pandemic: position paper of the European Socie. European Journal of Psychotraumatology, II(I). https://doi.org/I0.I080/20008198.2020.1780782

Jain, R. \& Chetty, P. (2017). How to interpret the results of the linear regression test in SPSS? Retrieved July I0, 2020, from https://www.projectguru.in/interpret-results-linear-regression-test-spss/

Khan, S. (2020). Bangladesh ranked 8th in global weekly increase in corona cases: WHO. Retrieved from https://newsd.in/bangladesh-ranked-8th-in-global-weekly-increase-in-corona-cases-who/

Moin, A. T., Sakib, M. N., Araf, Y., Sarkar, B., \& Ullah, M. A. (2020). Combating COVID-I9 Pandemic in Bangladesh: A Memorandum from Developing Country. Preprint, May. https://doi.org/I0.20944/PREPRINTS202005.0435.VI

Maswood, M. H. (2020). Bangladesh among lowest testing countries Retrieved from https://www.newagebd.net/article/I04658/bangladesh-among-lowest-testing-countries

Nubé, M., Asenso-Okyere, W. K., \& Van Den Boom, G. J. M. (I998). Body mass index as indicator of standard of living in developing countries. European Joumal of Clinical Nutrition, 52(2), 136-I44. https://doi.org/IO.I038/sj.ejen.I600528

Rashid, S. F., Theobald, S., \& Ozano, K. (2020). Towards a socially just model: balancing hunger and response to the COVIDI9 pandemic in Bangladesh. BMJ Global Health, 5(6), e0027I5. https://doi.org/I0.I 136/bmjgh-2020-0027I5

Shimanta, M. L. R., Gope, H., \& Sumaiya, I. J. (2020). Readymade Garments Sector and COVID-I9 in Bangladesh. June, I17. https://doi.org/I0.20944/PREPRINTS202006.0336.VI

Sohrabi, C., Alsafi, Z., O'Neill, N., Khan, M., Kerwan, A., Al-Jabir, A., ... \& Agha, R. (2020). World Health Organization declares global emergency: A review of the 2019 novel coronavirus (COVID-I9). International Journal of Surgery, 76, 7I-76.

Scott, J. (2020). This is the human impact of COVID I9 and how business can help. Retrieved from https://www.weforum.org/agenda/2020/03/this-is-the-human-impact-of-covid-I9-and-how-business-can-help/

Stature, Living Standards, and Economic Development: Essays in ... - (AU Komlos - Google Books. (n.d.). Retrieved from https://books.google.co.in/books?hl=en\&lr=\&id=_MtDGXjigWEC\&oi=fnd\&pg=PA60\&dq= standard + of + living

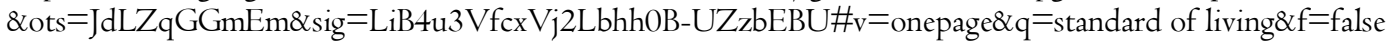

Suriani, H., Norlita, I., Wan Yonsharlinawati, W. J., Khadizah, G., Kamsia, B., Darmesah, G., \& Asmar Shahira, A. S. (20I2). Using Factor Analysis on Survey Study of Factors Affecting Students ' Learning Styles. International Journal of Applied Mathematics and Informatics, 6(I), 33-40. http://www.naun.org/main/UPress/ami/I7-667.pdf

Talukder, A. K., Sheikh, B., Rahman, M., Sheikh, B., Rahman, M., Engineering, G., Sheikh, B., \& Rahman, M. (2020). Tackling the Pandemic COVID-I9: the Bangladesh Perspective. April, I-I8. https://doi.org/I0.20944/preprints202004.0384.vI

Uddin, M. N., Alam, B., Islam, S. S., Arif, M., Alam, M. M., \& Kabir, S. L. (2020). Impact of COVID-I9 on food safety and security in low and middle income countries. Asian Joumal of Medical and Biological Research, 6(2), I30-I37. https://doi.org/I0.3329/ajmbr.v6i2.48043

Zannah, M. (2017). Re: Can anyone explain what is the difference between $B$ and $\beta$, in multiple regression?. https://www.researchgate.net/post/can_anyone_explain_what_is_the_difference_between_B_and_b_in_multiple_re gression/58eI Ibd32I7e2068f044adb3/citation/download

\section{Copyrights}

Copyright for this article is retained by the author(s), with first publication rights granted to the journal. This is an open-access article distributed under the terms and conditions of the Creative Commons Attribution license (http://creativecommons.org/licenses/by/4.0/). 